\title{
NATIVE SPIRITUALITY IN (RE)CONSTRUCTED PERSONHOOD: OBSERVING AND FILMING YURI VELLA
}

\author{
Eva Toulouze, Liivo Niglas
}

\begin{abstract}
This article ${ }^{1}$ is an attempt to understand what role spiritual matters play in the ideas and everyday life of a public figure quite famous in Western Siberia, the Forest Nenets writer, reindeer herder and activist Yuri Vella, and how the so-called religious practice is articulated in his life. In our reflection, we do not rely on any ad-hoc discourse, on issue-centred interviews, but on our fieldwork observation of speech and practice, a big part of which has been recorded on video with the aim of using it in the making of ethnographic films.
\end{abstract}

Keywords: personhood, identity, spirituality, religion, participant observation, ethnographic film

\section{INTRODUCTION}

The 20th century brought radical changes in the material and spiritual life of the Siberian indigenous communities: Soviet rule attempted to transform deeply not only social lives but also individual worldviews in order to achieve the project of inventing the so-called "Homo Sovieticus". This project has certainly not been achieved according to its initial aims. However, Soviet systematic endeavours have certainly had consequences on the natives' lives (see, for example, Leete \& Vallikivi 2011a; 2011b). They had to adapt to understandings very different from their own, while starting from a point radically different from the dominant, Russian, commonly accepted truth. Almost a century later, what is the result? What has been left of the northern natives' pre-Soviet worldview? How have concepts and practices changed?

There are different ways of approaching these questions. We (Eva and Liivo - we will refer to ourselves by first names) have chosen to concentrate on one individual, in order to understand in depth the kind of processes at work in personhood construction. It is clear that we understand personhood from a Western point of view. However, we are convinced that northern natives have had to find ways of adapting and surviving, and these ways have deeply af- 
fected their individualities. They have been individual as each person had to find answers to questions that were not community issues: children in boarding schools, young men in the army had to express individual agency in coping with new and barely understandable phenomena. We have concentrated on one individual, Yuri Vella, with whom both authors of this paper have interacted for almost fifteen years, living in his camp and keeping constantly in touch with him. Yuri is a peculiar person, particularly interesting to follow: coming from an ordinary native life experience, very much in compliance with the 'script' the Soviet regime had imagined for natives (Gray 2003: 48), he has developed a keen reflexive native consciousness, which leads him to constantly follow his own behaviour and his own actions, incomparably more than the majority of his kin and people in general do. His experience is certainly not to be generalised: it would be erroneous to pretend that Forest Nenets in general follow his pattern, he is more an exception than a rule, but he shows one of the possible intellectual ways open for a person of his generation. Other possible ways are double patterns - one in the forest, the other in the village -, conversion to Christianity, predominance of materialistic and positivistic understandings, for example. But Yuri's approach, while being unique because of his consciousness, is deeply embedded in a world that is shared by his native companions.

The materials we rely upon are of different kinds. They are mainly based on fieldwork: Eva has been to Yuri's place three times - in 1999 and 2000, for a cumulated time of five months, two of them in the company of the Estonian linguist Kaur Mägi. Moreover, she has met Yuri in other public events in Russia and abroad (1998, 1999, 2005, 2008). Liivo met Yuri for the first time in Tartu in 2000 and was thereafter invited by him to shoot a film about the Forest Nenets. He twice spent a month (in 2000 and 2001) at Yuri's place and made the film Yuri Vella's World (Niglas 2003). In 2009, Eva and Liivo dwelt at Yuri's camp for three weeks while shooting video footage for research and for a new documentary about him. Liivo returned to Yuri's camp some weeks later in the autumn to record additional material for the film during the coupling of reindeer. These fieldwork trips provided us with film material and several conversations, as well as practical experience of rituals. The film footage, more than 50 hours in total, is an additional fixed material and we may add to this the interviews in the numerous films made about him, and the content of the available part of the video archives he himself shot regularly between 1995 and 2001. 


\section{Methodology: observing and filming}

While staying in Yuri's home, our fieldwork method was mainly just living (Kerttula 2000: 3). We were engaged in our own work - Eva translating Yuri's poetry, Liivo shooting for documentaries - but as anthropologists we simply observed and participated in Yuri's everyday life. We carried water for sauna, played with Yuri's grandchildren and spent hours drinking tea and listening to Yuri's stories. There was no specific research plan, no thematic interviews. Therefore the spiritual issues as commented hereafter result from how they came forth spontaneously in a given observed situation. There are specific reasons why we focused on participant observation in our fieldwork at Yuri's place.

Yuri is a very active and outspoken person. He is constantly on the move, always doing something, be it taking care of the reindeer, checking fish traps, building a sledge or driving a car to a nearby village or town. It was very difficult to pre-plan a longer interview session with him because we would simply never know when and for how long we could do it. On the other hand, he is usually very talkative and likes to express his views on all kinds of matters. He likes to talk about himself, or, more precisely, whatever topic he is concentrating on, which he usually approaches through his own personality. In other words, although it is complicated to conduct a proper interview with Yuri, it is relatively easy to gather information from him. As fieldworkers we just had to participate in his activities and tried to keep pace with him while making our observations and collecting data.

This fieldwork methodology works well with the kind of filmmaking Liivo has carried out at Yuri's places since 2000. As a filmmaker, Liivo is reluctant to make interview-based films. Many documentaries use the interview - an informant or an expert, usually seated in a room, answering a set of questions posed by a researcher or filmmaker - as the main narrative device. In his film work, Liivo tries to harness the potential that is inherent in the real life behaviour of the film characters, including their spontaneous reactions to the presence of a camera. He employs observation as the main strategy in his filmmaking, but his camera is not limited to being merely 'a fly on the wall'. His approach emphasises 'being with' rather than simply 'looking at' the film subject. Filming Yuri means participating in his everyday activities with a video camera, which is not only a recording device but also a partner, whose presence enables Yuri to comment on his action, to discuss various topics and to construct his identity. The object of the video observation is not just Yuri's behaviour and insights, but also the role of the filmmaker in that observed reality. Therefore, although Liivo's filmmaking is observational in form, it is participatory in essence: filmmaker represents his subject's socio-cultural real- 
ity by showing a series of contiguous events, thus encouraging the audience to learn by observing rather than just by listening; and in order to "enhance the value of his material as evidence", he reveals his role as a filmmaker in the recorded events (MacDougall 1998: 134) ${ }^{2}$.

Our research project as a whole thus included both fieldwork and filming. The important part of the information and insights employed in the present analysis were achieved when Eva and Liivo stayed together at Yuri's forest camp in the summer of 2009. Our aim was to film video footage on Yuri's life history, focusing on his different biographical episodes. We planned to use these episodes both for the research and for the documentary film. Eva's role was to engage Yuri in informal conversations while Liivo recorded it with a video camera. Our plan was to ask Yuri to take us to the places that had some sort of significance in his life history or had influenced him as a person. We hoped that visiting these places would trigger the flow of information from Yuri and reveal his emotions in the way it could not have been achieved in a normal interview situation. Thus, while previously Eva and Liivo had worked independently, one doing fieldwork, the other making a film, this time we decided to join forces and use a video camera as a proper fieldwork tool.

Using a video camera in ethnographic fieldwork is quite common these days. Some researchers see it merely as a 'note-taking device', others use it more systematically in the data collection, analysis and representation phases of the research in order to focus, for example, on aesthetic, corporeal or other sensory aspects of reality under study (Pink 2007; 2009). In the case of Yuri, the video camera had an important methodological value for us. It provided us with the mechanism for studying his self-representation. The role of the camera in the construction and representation of personal identity is one of the methodological devices that film can offer to anthropology. For example, Jean Rouch put the idea of performance and role-playing at the centre of his filmmaking. He has stated that "when people are being recorded, the reactions that they have are always infinitely more sincere than those they have when they are not being recorded. The fact of being recorded gives these people a public" (Blue 2006: 268-269).

Yuri has repeatedly stated that his life is a museum (Toulouze 2004): it is on display for others to see and to learn from. He is always ready to demonstrate his way of life and to explain his understandings of reality to the audience, be it by hosting people (researchers, politicians, filmmakers, etc.) in his camps, delivering public lectures, giving interviews to the mass media, or participating in TV programmes and documentaries. As the main aim of Liivo's filming was to make a feature-length documentary about Yuri, we offered him a potential film audience that he could relate to and perform for. He is well experienced 
in manipulating visual media (Niglas 2005), and he knows how to make an impression on the audience.

Yuri is a highly media-conscious person to work with. He has familiarised himself with the film medium by watching thousands of fiction and documentary films: he has a huge collection of VHS tapes that he likes to play on a TV set in his forest camp, and whenever there is a chance to watch TV (when the TV signal in his forest house is powerful enough due to the weather conditions, or when he is visiting friends and family in nearby villages and towns) he often spends hours watching several films in a row, sometimes until early morning. For more than five years, when working officially for the Research Institute for the Revival of the Ob-Ugrian Peoples, he also systematically used a VHS camera to document his own life in order to demonstrate how the natives live in the region.

Yuri is personally interested in film as a process. He consciously cooperates with the filmmaker, both by thinking technically (answering questions so that they could be easily edited), visually ("What a beautiful sequence you could have had!") and in terms of the message. Thus, the mere presence of the camera is a catalyser, which provokes information. We are conscious of the peculiar quality of this information: it is simultaneously explicit, biased and controlled. As for Yuri, film is a way of forwarding the messages he has been thinking about. He is, on the one hand, careful and aware of what he says, while on the other he says certainly more than he would without a camera pointing at him. The camera makes him talk, which is certainly partly a need for him to find clarity in his own thoughts (the 'sofa of the psychoanalyst'). The camera as a recording and representation device encourages him to put on a good performance, to show his storytelling and reasoning skills. In many cases, the camera just records the same things he has stated elsewhere, in conversations or in his stories and poems, but sometimes it makes him approach his life experience from a new angle. By talking to the camera, he constructs both his narrative and himself, giving us a kind of personal 'official' discourse about his biography. 'Official' does not mean it is false or invented. It just attempts to give a coherent narrative of life's naturally heterogeneous layers and incoherent course. In this 'official' autobiography there are iconic stories, emotions, turning points, philosophical developments. It reveals more clearly than anything else who Yuri attempts to be, not only for us, but mainly for him. Thus, it participates actively in his production of sense and the construction of his identity.

This article is about one individual. It is one possible way to approach worldview questions, and certainly not the least interesting, for it allows one to go deeper into reality's complexity without having to cope with differences between individuals and the need to generalise and to modelise a large amount 
of diversity (as in Pentikäinen 1971). Still we cannot avoid the necessity of simplifying and modelising, which reflects the attempt to organise the thinking of one single individual. His personal effort to produce order is certainly of great help, although we are aware of the possible manipulation this control on the information flows allows. But the manipulation itself is also of significance.

\section{About native spirituality: an attempt to define what we look for}

The kind of evidence we are looking for is intuitively clear while it is tricky to formulate and to define, for in Nenets culture the boundaries are not as clearly drawn as they are in Western scientific understanding. If we were missionaries or officials, we would certainly speak about Yuri's 'religiosity', about his 'beliefs's , about his 'religious thinking', even about his religion. We would have no scruples in using a word which refers to our own default worldview and covers an unambiguous sphere. But we are anthropologists and we know that the way a Siberian native understands the world and the connections within it is not to be summarised with the words 'religion' or 'belief'. These are exogenous, they have been imposed upon the natives by alien mental structures, by people who, being professionals in that sphere, could only interpret the unfamiliar by using familiar categories: their thinking habits and their languages did not and still do not provide them with appropriate tools, they do not correspond to the realities they are supposed to cover. At the same time, those categories have been accepted, interiorised by the natives themselves (Asad 1993): in contact circumstances, speaking a language that is not theirs, they took over the conceptual tools introduced by the Other and used them while confronting the attempts to penetrate their consciousness. These tools became a kind of weapon: even if they were not well suited for their case in a theoretical way, pragmatically, they could still be advantageously used, when nothing else was available.

We are thus facing a challenge: to express what is not to be reduced to the concepts we have in our kit box. The closest is perhaps 'ontology', which is certainly fit (as worldview is) for the holistic approach it induces, but seems not to be sharp enough to be of much help in defining boundaries. We have chosen here the word spirituality, giving it very much the sense used by Hann (2007: 387). Nevertheless, even this term remains critical: for, in concept as well as practice, there is no clear boundary between spiritual and profane in the world of indigenous people in Western Siberia. The spiritual aspect is in all deeds, even the most trivial: the choice of a place to urinate in the forest is an act directly embedded in the notion of sacred; in the permanent dialogue 
and negotiation one is involved with all the forces that surround the human being. Eva's fieldwork shows this eloquently: in 2004, during an offering in a Khanty forest camp, prayer was thoroughly intermingled with jokes and laughter; slaughtering reindeer in order to eat meat is no less a sacrifice (we will come to this later on). The clearly defined realms of sacred and profane, of earthly and spiritual, are part of our worldview. From this point of view, the choice of this issue is clearly connected to the understandings we have grown up with. However, the holistic approach does not annihilate the sense of sacredness; it just refuses to isolate it and inserts it into a continuum. We will concentrate on one end of this axis. To put it in other words, we will try to follow Yuri's ways of negotiating his own place in the world with the other forces - human, natural or spiritual - that must be domesticated. The three aforementioned spheres are not thoroughly distinct from one another, forming three layers of one whole, they are also disposed in a continuum without clear boundaries. By limiting our subject (for scientific approach, Western-centred, requires limiting), we impose our worldview; but still, we consider we may do it, for this understanding has been dominant in the region for some time now, and these concepts are used by the natives themselves. Moreover, we suspect that Yuri himself is very much influenced by this way of reflecting on the world. In any case, communication with the spirits exists and is undoubtedly of great importance for Yuri and his family.

\section{(RE)CONSTRUCTION OF PERSONHOOD}

In order to appreciate how the perception of the sacred sphere interacts with other aspects of Yuri's worldview, we must start by giving an overview of his biography (see also: Toulouze 2003). This explains how from a typical Soviet start in life, the course of his personal history has led him to occupy a unique position among the intellectuals of the Russian North.

\section{Yuri Vella's short biography}

Yuri had quite an ordinary Soviet childhood. After the death of his father, who was a kolkhoz reindeer herder, he moved with his mother to Varyogan, a village founded on the upper Agan River in the 1930s by relocating nomadic Forest Nenets and Khanty from the region into one settlement. There he went to school and visited as often as possible his grandmother Nengi, who shared with her grandchild her stories told in Nenets. In Varyogan Yuri could attend 
only elementary school and had to move to Agan - a bigger, predominantly Khanty settlement down the river - in order to continue his studies in a boarding school. Afterwards he started high school in the regional centre Surgut, but soon got into conflict with his Russian language and literature teacher, who did not appreciate him writing poems, and he left Surgut without finishing school.

Yuri's further years did not differ from most native boys' course of life. He served in the army, was employed in different jobs, and married a native girl, Elena Taylakova, from a Khanty family living in Agan. One year after completing his compulsory service in the army, he decided to stop drinking and started therapy with a well-known Sverdlovsk-based physician - this was one original decision that he made quite early. Another step, which was not so commonplace ${ }^{4}$, was to move to his wife's place: as Elena was the youngest in her family, she was supposed to live with her mother until the latter's death. Later they moved back to Varyogan, where Yuri earned his living as a hunter in a state enterprise and spent long periods in the forest, sometimes with his family. Meanwhile, on the advice of a Russian ethnologist, Izmail Gemuyev, he applied for distance education at the Maxim Gorky Literature Institute in Moscow: in order to do that, he first had to finish high school and then to attend university courses in poetry while working full time; for two years he worked as the president of the rural soviet of Agan, but after realising that his attempt to turn the local policy towards the indigenous people had failed due to the significant number of Russian newcomers living in the area, he went back to his profession as a hunter.

In 1990, when the Soviet economic and political system was crumbling, Yuri completed his first poem collection, which was published the next year ${ }^{5}$, and decided to leave the village in order to live with his family in the taiga. He bought ten reindeer and moved to the area where his paternal ancestors used to live as reindeer herders and hunters. However, like many other areas in Western Siberia, where oil was discovered in the 1960s, his ancestral territory had suffered from the ruthless exploitation of the Soviet oil industry.

Yuri has lived there ever since. Today he has twenty-four people under his responsibility - daughters, sons-in-law and grandchildren - and he manages a much larger reindeer herd. Meanwhile he has published several new books ${ }^{6}$. As the territory where he retired with his reindeer is on the land used by Lukoil, the giant multinational company exploiting oil resources in the region, Yuri found himself in a conflict with the oil industry and also with local authorities. He had to become politically active and start a fight for indigenous rights in order to survive as a reindeer herder in one of the most important oil-producing regions of Russia. Since then, he has been known as an activist who often uses very clever and exceptional ways to fight for the rights of natives to their tra- 
ditional way of life. This makes him a very uncomfortable 'trouble maker' for Lukoil and regional authorities.

\section{The revelation}

Yuri, as we have pointed out, has experienced an upbringing very similar to that of other young men from the taiga. Although his connection with his grandmother was quite close, he did not live in her home but in a boarding school, where the ruling values were those of the communist regime, i.e., materialism and anti-religiosity. These values were given to him by default. He did not discuss them at the time. One of his jobs ${ }^{7}$ was working as a propagandist in the 'Red chum' (the propaganda corner in the village). Actually, Yuri told us that he had applied to be accepted into the Communist Party three times but had been rejected each time. This shows that he had then no doubt about the righteousness of the Party's politics and of the general political discourse, part of which was atheist education. As a whole, in the remote parts of Russia, it was actually a convincing story for ordinary citizens who had no basis for comparison, as they had never gone abroad nor seen anything else.

To the ethnographer Andrey Golovnev, who, in 1992, enquired about his understanding of the Nenets gods, Yuri answered that for him, the word num had long meant only sky, and it became the name of a god only when later he read in books that this ordinary word was also the name of the Nenets' main god (Golovnev 1995: 380). This provocative answer indicates that in his youth Yuri was not explicitly instructed in the Nenets' worldview. He discovered this aspect of his culture only later on. In any case, this is the way he presents his biography: there is a clear turning point, as in a kind of Pauline religious conversion.

There is a long and interesting episode in the video footage shot in the summer of 2009 at Yuri's summer camp. It shows how the mere presence of a recording camera can catalyse a long and uninterrupted flow of information with almost no questions from the filmmaker. It was our first day at Yuri's forest camp and one could sense that Yuri was excited about being filmed again. It almost felt as if the camera was an old visiting friend, with whom he was eager to share his personal news and insights after so many years of separation ${ }^{8}$.

Yuri was digging soil in a small garden next to a reindeer enclosure. When Liivo approached him with his camera, Yuri started a long monologue that lasted all in all for almost an hour. Whenever Yuri ran out of thoughts, he returned to digging. But in a short while, seeing that Liivo continued shooting, he took up a new topic, even if the camera was filming at the other end of the 
garden. Liivo took it almost as a test - to see how long and on what issues Yuri would keep talking without any interference from the filmmaker. The topics he brought up were obviously very relevant for him at that moment. He talked about the garden and the difficulties of maintaining it; about his new passion for sledge building; about his concern over autumn pastures where reindeer go for the rut and the oil people to hunt and drink. Surprisingly, one of the topics was the revelation that changed his life many years ago.

This happened while Yuri was studying at the Literature Institute. During his first years at the institute, Yuri underwent a fascinating process: he discovered the notion of culture ${ }^{9}$. During the first year at the institute, the students had to study ancient Greek and Roman philosophies and Yuri discovered that they were very much universally understandable by people from other cultures (much more so than Oriental philosophies). He started realising that the Nenets also had a culture of their own: while the teacher talked about classical cultures, Yuri reflected in comparison about his way of thinking as a native. He thus discovered his own culture not through the elders or his kin, but by going far and facing other, different 'cultures'. Actually he considers now that school had not transmitted any hint of high culture either to him or to his daughters, and that it just destroyed what they knew without bringing them anything in return. In Yuri Vella's World he states: "Children live in a boarding school. Returning to camp, they don't know anymore how to live there, how to heat a stove, from which side to approach reindeer. They have to learn all this over again. But there's no work in the village. Our children graduate high school or technical school, but they don't find work. And so they lounge around. For them, what is there to do? Nothing." (Niglas 2003)

Studying at university allowed Yuri to discover that there were real intellectual and ethical values in the Russian and 'Western' culture overall. He discovered world literature as well as art and classical music, all of which was kept far from the natives' reach. He also discovered the contradictions between the discourse he was accustomed to and historical reality. Once a lecturer commented on the existence of intellectuals and poets among anti-Bolshevik groups, known as the Whites, during the Russian Civil War in 1918-1921, and Yuri discovered that there were values on the 'other' side too - loyalty and honesty, for example, which had been denied by their teachers at school, who had always presented the Whites as 'bandits'. It was one of the first contradictions that led Yuri to start doubting the whole system and trying to judge always by himself, without relying on any authorities' discourse. He has learnt to doubt: he started applying this new knowledge to all domains in life, subjecting all information to critical examination dictated by his own reason. For him, authoritative speech has entirely lost its weight, and forever. 
However, Yuri discovered something else as well. He realised that what his people had been deprived of by Russian colonisation was also culture. Until entering university, he thought as they had been told that they were a primitive people, and that Russians had brought them civilisation ${ }^{10}$.

\section{(Re)constructing an indigenous identity}

Now, by discovering the Others' culture, Yuri also discovered his own, and from that day on he started defending the Siberian natives' values in any situation with which he was confronted. One must admit that not only culture was at stake in Western Siberia's oil industry development, which started in the 1960s and achieved a peak in the 1970s: the natives' physical life started to be endangered, as the environment around them, which they relied upon, was gradually being destroyed by air, water and soil pollution. While the political conditions in Russia changed, confirming the suspicions that had already arisen, the natives' position in their own land became more and more ambiguous: on the one hand, they were provided with the so-called kinship territories whenever they chose the traditional way of life, ${ }^{11}$ on the other, as those territories were often already being used for oil production, conflicts between oil workers and reindeer herders were multiplied. For oil companies as well as for many newcomers in general, the landscape is a place where there is nothing, which is empty, because there are no signs of buildings or other marks of civilisation. Therefore they occupy it irrespective of the signification it may have for the indigenous people. ${ }^{12}$

Yuri wants to show the depth of the cultural layer inherent in the Agan natives: he likes to exhibit their skills in deduction, in reconstruction. 'Playing detective' is one of his favourite attitudes ${ }^{13}$, which we have witnessed many times. A good example of Yuri's performance as a detective is captured in a sequence Liivo shot in May 2001.

Yuri is walking in the forest looking for the herd. He reaches a spot without big trees not far from a small lake and informs the camera that there was once a campsite there. The only visible evidence of the campsite that the camera can see is a wooden detail of a traditional conic tent (chum), half-hidden in the moss. Yuri shows where the entrance was, detecting it from the location of a tiny pile of rotten tree branches that used to be firewood that was used to heat the chum. As there is no sign of a fireplace, Yuri claims that people used an iron stove and therefore they lived there either during or after the war. He points out that the people lived there in winter because the trees were chopped down when there was snow - he shows a tree stump with traces of an axe blade, 
which is half a meter high. He adds that the campsite was used temporarily, probably in order to hunt for squirrels or wild reindeer. And then he gives a personal twist to his interpretation, speculating that the occupants of this site could have been his father and mother, because, according to his mother, that is the area where they lived after the war.

The aim of this performance for the camera is clear: to show that the natives are able to see and interpret, while the white man who sees the same things does not understand what messages objects, landscape and animals convey. As Yuri explains in the same sequence, the white man is blind and does not wish to see, where there would be so much to see. That is why Siberia is presented like a white stain. But the landscape, the trees, the soil, the objects speak: they are not only the remains of the native culture; they may be part of a culture still alive. And the way people know and see it is a direct expression of its peculiarities and of what this culture may contribute to universal knowledge.

Yuri's contemporary insertion in traditional culture is the result of a conscious construction that started after he graduated from the institute. He built himself up in several ways. In 1990, he changed his way of life totally by becoming a reindeer herder: he had never lived permanently in the wild; he left the village and started a new life from scratch. It was actually very hard on his wife, who did not want to leave the life she was accustomed to and which she liked. Becoming a reindeer herder was his own personal project, corresponding to his personal dreams and to his peculiar vision. With his wife's help he built dozens of kilometres of fences, several log huts in different camps, roads to them, even bridges. He learned to be a reindeer herder, albeit he had never lived with reindeer. At forty, he attempted to learn skills that one should acquire while a child. Part of this reality is the fact that he is still rather clumsy as a reindeer herder. He is not good at catching the reindeer with the lasso. This explains why Yuri, who is usually very happy to be filmed, gets easily irritated when filmed during reindeer catching. He often mentions that he is "a young reindeer herder". Sometimes he turns to that story in order to show the proficiency of Russian reindeer herders. For example, in his personal video archive there is material recorded at the Congress of Private Reindeer Herders in 1999, which shows him in his introductory speech sharing with the audience how he asked a reindeer herder in Lapland how many ways he knew for castrating a male deer. As he received the answer "one", he added proudly: "You all know that our elders know six ways for castrating a deer, depending on the result you want. I myself know three of them, and I may use only two, because I do not have my own teeth anymore." But more often this story is meant to convey that Yuri has not achieved the proficiency of most herders. Compared to his neighbours, the difference in knowledge and ability is clear: as we observed during our fieldwork 
in 2009, his Khanty neighbours were very proficient in preparing the reindeer, and they ate more parts than Yuri and his wife did.

Yuri's construction is heroic and desperate. What he did for his material life, he also did with his mind. He bent it in order to create a new awareness and to build up a whole indigenous identity, while he had been condemned to duality by the circumstances of his upbringing. He attempted to reunite his own world. Of course, there are no witnesses to how he struggled, except perhaps his wife, who nevertheless was in enough trouble herself, trying to adapt to a life she had not chosen (and that by now she has learnt to love). However, we may assume his struggles were hard.

Thus, what he is attempting to do is not to invent a new identity from scratch, but to reunite his divided identity, to find anew what has been lost and annihilated, to reconstruct himself. In the same way, he learnt to live within native spirituality, which is now fully part of his identity. We do not know whether he has the same apprenticeship feeling in so-called spiritual matters, but we are going to explore this issue in the following part of the article.

\section{A SERIOUS 'ENTERTAINMENT': SACRIFICIAL PRACTICE TODAY}

Once, in 1999, when Eva was living at Yuri's place, they were visited by a couple from Num-To, to whom Yuri had promised to give an old snowmobile. They spent about two weeks at Yuri's place. Once Yuri asked the man, a Forest Nenets:

- Do you know how to make a god?

- No, I have never made any.

- That's good! The result is better when one makes a god for the first time. Mine is too old. I must have another.

Some days later, as we were all together indoors, Yuri gave his guest a piece of wood and a knife and asked him to start carving. He gave him instructions in order to have the piece of wood carved into a rough anthropomorphic shape. When it was ready, Yuri wrapped it in tissues and performed a short ceremony. At the end of it, he addressed Eva and said: "Well, this is how we entertain ourselves." The tone was ambiguous. Yuri watched Eva's reaction attentively, with a hint of a smile, which was clearly open to various interpretations.

For us, this last remark shows Yuri's attempt to integrate Eva's potential reaction into his discourse. He had not known her for long by the time and he supposed that, like almost all the lutsa ${ }^{14}$ he had formerly met, she could con- 
sider his beliefs as ridiculous, and tried to protect himself by being the first to laugh at them. There was something pathetic in Yuri's defensive position. It illustrated how injured the native people were in their relations with outsiders and how frequently they had been ridiculed by them. ${ }^{15}$ Or may we infer that Yuri still remembered how he would have reacted himself not so long ago? Was there a part in him that still distanced itself from what he attempted to be, in spite of long-term habits? Actually this cautious behaviour is not accidental. We can identify it in an episode in Yuri Vella's World, where Yuri talks about the President's reindeer.

Yuri is feeding dried bread to reindeer and explains that there is a custom to present a friend or a relative with a reindeer that stays in the herd of the giver, and that it is possible to conclude how lucky its owner is by observing the behaviour and the fate of the reindeer. He goes on saying that some years ago he and his wife had dedicated a female reindeer to the president of Russia, and that when her first calf was born, they learned that Boris Yeltsin, who was the president at the time, had become ill. Yuri continues: "We performed a rite of sacrifice, offered the calf to the gods so that the President would recover. Soon the mass media announced that the President was well again." Yuri does not explicitly connect the two events; he leaves the conclusions to be drawn by the audience. We have already commented on this in a former article: "He does not assert that the sacrifice was the reason for the president's recovery, but the fact is that he was healed. This is an interesting point in Yuri's behaviour. Clearly, he believes in the connection between the reindeer and their owners, between the deeds and their consequences. At the same time, he is perfectly acquainted with the Western scepticism about all this kind of 'superstitions', and he presents them in a way unobjectionable to the outside world." (Niglas \& Toulouze 2004: 106) The influence of modern values proceeding from the Soviet materialist understanding upon traditional way of thinking is very clear here.

\section{Offerings and sacrifices}

Sacrifice is the main form of communication with the spirits practised by the Siberian natives. It punctuates the year and the main periods as well as the main moments in people's lives, and helps people to express veneration towards the divinities who rule their lives - the local ones, the ones represented in natural elements as well as the protectors of the clan. An offering, a sacrifice is a way to draw their attention to the people who perform the sacrifice and who ask for well-being. They also accompany any kind of communication moving from below towards the highest spheres. 
We have had the opportunity, separately and together, to participate in several ceremonies we shall here recall. In 2009, we had brought Yuri as a gift a long piece (3 metres) of white fabric. It is one of the accessories for sacrifices and offerings. It was supposed to be a welcome gift, as Yuri had declared to Eva once in 1999. While during previous visits when Eva had brought one, it had been put aside and certainly used by Yuri when needed, this time we were thoroughly involved in its use, most probably because of the interest Yuri had in our filming. As our visit took place in the second half of July and beginning of August, we were not expecting to participate in blood sacrifices, for the reindeers change their fur at that time of the year and herders avoid slaughtering them before their skin is fit for use. However, the family was longing for meat, so they started at the end of July to follow the reindeers to see whether at least one of them would have a proper skin. As we had only some days left before returning to Europe, Yuri addressed the two of us asking: "Which of you bought the fabric? Is it a gift from one of you personally or from both?" We answered that it was our common gift. What would have happened if only Liivo or only Eva had been the donor, we do not know - would Eva being a female have had an impact? Certainly, the presence of the camera was a key factor. He knew we wished to film and he was ready to adapt his deeds to the needs of filming. Anyhow, Yuri then told us to choose the use for the fabric ourselves, the situation being the following, as he explained to us: the proper way to do things would be to proceed to a reindeer sacrifice with the fabric being loosely knotted around the neck of the reindeer during the sacrifice, dipped in blood afterwards and brought to a sacred place we had expressed the wish to see not far from the Vatyogan River. But there was no time: the reindeer would not be sacrificed until our very last day because of the skin. So we were given a choice: either to put the fabric aside for the last day and perform the first part of the full ritual or go to the sacred place before the sacrifice and make a simple offering with the fabric. We chose the second alternative for both general and self-interested reasons. The latter was the needs of the film Liivo was shooting, as the topic of the film was directly connected with the Vatyogan area. The general reason was also related to the same piece of land. The area by the Vatyogan River was a critical place for Yuri's herd and he was deeply concerned about it. It was the rutting place for his reindeer, but the governor of Khanty-Mansi region had given the same land to the Lukoil hunting club. Yuri had been unofficially given a copy of that document some months earlier and thus discovered why his reindeer were often harassed during the rut by hunters. He had decided to chase hunters from the Vatyogan shores and planned to build a provisional log cabin there for this purpose. To have an offering and a prayer in a sacred place situated in the middle of a disputed area seemed to be appropriate to Yuri's 
needs at that very moment as this had been his main concern during the whole summer. Moreover, the summer had been mosquito-free, and the reindeer, who are usually attracted home by the smoke produced by burning fresh moss in the so-called reindeer house (olennyi dom), were not bothered by insects and roamed freely on the Vatyogan River, causing deep concerns to the herder. So, to have an offering in the area seemed to be an appropriate decision. Yuri had previously suggested that Liivo's film could be about the Land of Love (i.e., the Vatyogan area where the rut was taking place), hinting that it would probably also include him fighting with the oil people there. By carrying out a ritual in the place, he was offering the filmmaker a powerful episode that would intensify the film narrative.

Thus, we went with Yuri and his three-year-old grandson by car to the sacred place, which was a hill of elongated form, in the centre of which there was a natural treeless sandy corridor. The heart of the sacred place was the top of it, where besides a metal pole hammered into the ground proving the oil workers' presence, there were recent reindeer skins hanging on trees and pieces of reindeer hair still dragging across the ground. Before the sacrifice Yuri tore three pieces from the fabric: he gave one to his grandson and one to each of us. He explained that Grandmother (his wife) would sew the piece on the child's malitsa, the anorak-type clothing for men. There are two types of malitsa, the winter one and the summer one, but both have a hood, and the piece of sacrificial fabric is sewn on the back of the hood as a protective mark. While Liivo was filming, Yuri addressed the gods, in Nenets as he always does, his prayer being interrupted by repetitive bows and turns clockwise. He held his grandson by the hand and the three-year-old child imitated all his grandfather's gestures and movements, except at the end of the prayer, when he clearly got bored and started playing on the ground. After the prayer, Yuri asked Liivo to climb up a tree and knot the fabric around a tree branch in the proper way. Before climbing the tree, Liivo gave the running camera to Eva and asked her to continue to record the ritual. While he was climbing, Yuri kept shouting "Wow, wow!" and asked the child to do likewise. ${ }^{16}$ After Liivo had come down, Yuri asked him to walk around the tree with him and his grandson, while Eva filmed. Yuri set the order by age: first he, then Liivo, then the child. Yuri interfered when the child wanted to walk between him and Liivo. Eva was not involved, not so much because of the camera, but because females do not participate actively in offerings.

This is one example of an offering without a blood sacrifice. In the following sections, we shall present other examples of sacrifices of reindeer in connection with both sacred places and prayers that are pronounced during their performance. 


\section{Sacred places}

People make sacrifices and address the gods in special places. These are places felt to be connected with the spirits and anyone having a 'spiritual' experience at a specific site may start a tradition of a sacred place there - in the beginning for himself, later on it may spread and become more widely used, as with the one on the Vatyogan, at which Yuri sacrifices. While driving there in his four-wheel-drive minibus ${ }^{17}$, Yuri explained into the camera the probable origin of this sacred place:

A $k a p i^{18}$ lived in that area and once, while hunting, he got to the hill and saw it was a nice place. He started to walk back and suddenly heard a bell ringing. He returned and looked for the bell, but couldn't find one; he moved and heard the sound again. So he decided it was a sacred place.

The main sacred place close to his camps has been destroyed: it was on the spot currently occupied by the oil workers' village Povkh, and more precisely by the offices of Central Technical Engineering Service. Actually, according to Yuri, several "bosses" died at their working table in this office, and so he added: "That shows that the sacred place is still functioning."

However, some sacred places are only for him and his family. One, for example, is not far from his former winter camp ${ }^{19}$. It was chosen because a swan nested on it, and Yuri felt it to be a sign. It was here that the first sacrifice Eva attended took place. Its circumstances show that it was all but an entertainment.

In 1999, Eva had just arrived with Yuri and his wife from Helsinki and they found that there was no meat in the camp any more. In the evening, Yuri and his wife discussed which reindeer to eat. On the following day they all went to the place where the herd stayed, in a corral further in the forest. Yuri spent much time inside the fence with his grandchildren but by the evening there was no reindeer chosen. Yuri behaved according to what he had said in a previous congress of private reindeer herders: one was too slim, the other too nice, the third too old, it was impossible to decide which would be slaughtered. But during the night Yuri had a dream. He saw that Death was hanging around, looking for his wife. He decided instantly after having awoken that a sacrifice had to be made, in order to expel Death from the camp. He went back to the herd with his wife and took three reindeer, which they brought to the camp. After lunch he made a short speech: "We are going to make a sacrifice, no cameras or recorders can be used, and leave your bad thoughts behind in the camp." The first part of the speech was clearly addressed to Eva, who had a camera and a minidisk recorder, but the second could well have been addressed to his wife, who had been very irritated the whole day. The sacrifice was held in the private sacred 
place, in the presence of the whole household: his wife, his second daughter and her two sons as well as Eva. The ritual was very similar to the others we had witnessed: having tied the reindeer with a lasso, and put some whitish fabric around their necks, Yuri addressed the gods. Then he slaughtered the reindeer by knocking them down with the back of an axe and then pushing in a knife under their front legs in order to stab the heart, and behind the neck to hit the brain. All the time until the legs of the reindeer became still, Yuri talked to the gods and whipped their bodies with the lasso, as if encouraging the animals to run faster, for the movements of the reindeer's legs represent its galloping towards the other world and when the reindeer remains still, it means he has arrived. When the sacrifice was over, he poured vodka for "those who can drink it" ${ }^{20}$ and everybody took some food from the small table of food and drink offerings. Then the longest part of all started - the skinning and the cutting of the meat, as there were three reindeer. The male animal genitalia were thrown up into a tree, and the heads were also hung on the same tree. Then we went back home on sledges pulled by a snowmobile.

This story shows how serious Yuri is about sacrificing. As long as only his comfort was at stake, he could linger and give his reindeer time. But as soon as the situation became critical (the dream), quick action was required. The fact that he forbade any kind of recording ${ }^{21}$ was clearly another sign of the seriousness of the situation: it was not meant to be an exotic display, but a real ceremony with a real purpose, not fit to be mixed up with a public show of local identity. It was designed for a higher purpose, to protect the inhabitants of the camp from impending death. Actually we learned later that in those days a Nenets woman in the village of Varyogan died. Yuri presented this information as proof that the sacrifice had been successful and that Death had to turn to another place to catch his prey. ${ }^{22}$

\section{Prayers $^{23}$}

The performer of the sacrifice - which is always the oldest of the men - is the one who prays in a loud voice. And Yuri does it in Nenets, although it is not a language he uses every day. Actually, in the last years, many of his Nenets partners in conversation, elderly men, have died. As he is married to a Khanty woman who does not know Nenets actively, he never speaks it at home: their daughters were brought up in Russian and so have their grandchildren. Therefore usually there is nobody around who understands Nenets. His praying in his mother tongue is thus quite annoying for his wife. Once in 1999, during a meal, she said: "You have talked too long. What could you have to say so 
extensively?" He answered: “And I didn't by far say all I wanted." Actually, for him his prayer is as a private conversation, an address to the gods, and its form seems quite free: one may recognise very short formulas in the address parts, but the core of the text is quite flexible, as proved both by this fragment of conjugal conversation and by the way the prayer is pronounced, as clearly Yuri is looking for words that match his thoughts at the moment. Still, this freedom according to which every prayer is a single event represents a choice of formulas that may be repeated, and thus, the composition of prayers reveals, like many other features in this field, a limited flexibility (see below).

During the previously reported offering in 2009, the text of the prayer was the following, according to Yuri's own translation from the video tape into Russian:

Eh, Old Man of the Vatyogan! Our guests, those two ${ }^{24}$, because they walk on this land, have brought you as an offering this small pieces of fabric. Receive this offering with your right hand. Protect well your land from those who threaten it. Not only your land, but our land as well. ${ }^{25}$ Let our reindeer never be without food, let our reindeer always find their nourishment here. ${ }^{26}$ Let the other animals in their nests never be without food. Let the animals never meet distress. Let fish always dwell in your former riverbeds ${ }^{27}$. Old Man of the Vatyogan, look well after this land; let the plants grow well and the lichen sprout well. Let the reindeer calves always find food between the legs of their mothers; let them always find lichen and mushrooms ${ }^{28}$. Continue to add good days ${ }^{29}$. Let the men walking on this land never meet misfortune. Let people always meet each other with a smile. Eh, Mistress of the Agan, you too, look here, take you too this offering in your hand and bring these fabrics to your lips. Let your hand touch this offering. And help the Old Man of the Vatyogan to guard this land. Eh, Master of the taiga, you too, look here. You were, at some time in the depth of the centuries, also assigned the task of protecting this land..$^{30}$

Some remarks about this text. First of all, the addressees: Yuri, as he emphasised in his own commentary on the translation, addressed three gods at different levels. Two of them were local divinities, one of them ruling the closest river, and another the whole basin. The third god was a very general one, the master of the taiga, who seems to be totally unconnected with the places themselves, but is the protector of some kinds of beings - in this case, he is the protector of vegetation. In terms of structure, the introduction explains the offering, and begs for its acceptance; the second part expresses what is wished for in exchange of the offering. Actually our presence is just a pretext: we, the visitors, seem to ask for permission or to express gratitude for the permission 
to walk on these lands. Yet, the demands do not come from us, but from the people belonging to the gods. There is one main demand: protection of the land against those who threaten it. But Yuri mentions them just once; he prefers to insist on the positive demands. The 'beneficiaries' of the demands are first of all the fauna and flora: the reindeer, the other animals, the plants; then again the reindeer and only after them the human residents. Thus the prayer is focused on nature and men are present as part of nature, with wishes most similar. We do not know if and to what extent Yuri chose the wording of his prayer thinking about the future film about the Land of Love and about his fight with the oil people there.

Actually we have another video recording of a sacrifice described below, in which there was also a verbal dimension. In December 2000, Liivo filmed a ceremony whose main aim was to provide Yuri's kin in the village with meat. Yuri brought from his camp three reindeer, one of them white. The sacrifice was held in the small pine grove behind his village house in Varyogan, and his kin attended it. Actually there were also non-natives, either husbands of his kinswomen or acquaintances (one Ukrainian). All the men were involved in the ritual slaughtering. They followed the rules of traditional sacrifice: the men stood in one line side by side while Yuri knocked the reindeer down with the back of the axe before stabbing the animals in the heart and behind the head. After having skinned the animals, he divided the meat among the different households of his family. The ceremony was concluded by another ritual act: Yuri's son-in-law (the father of his youngest daughter's baby), instructed by Yuri, dipped a small piece of reindeer hide in blood and drew two circles on the house: first on the wall facing the grove and then on the wall to its right.

Yuri prayed two times during the sacrifice: the first time shortly before stabbing each reindeer and then later again because the legs of one of the stabbed animals were still moving. We have the video recordings of the prayer before the slaughter of the first and the third reindeer. In the case of the first, a white reindeer, Yuri addressed the heavenly divinities - Father and Mother of Heaven. The other address was general, without any mention of a concrete god. The texts were simple and short, with two main themes: asking the gods to accept the offering, and protect the people called their "children". ${ }^{31}$ The second moment in the ceremony when Yuri spoke - for quite a long time - was when the three animals had been knocked down and stabbed one after another. They were actually dead, but one of them still moved its legs. The lasso was put around his neck and Yuri talked to the gods while shaking the lasso, as imitating the movement of reins. Then he addressed different gods, most of them local: he started with the one of Varyogan (Tupka Nat in Nenets), then the Mistress of the Agan, and then the Old Man of the Forest. At this point we notice that the 
structure is pretty much the same as in the previously reported offering: firstly the divinity of the particular place, then the master or mistress of the larger river basin, and then the master of the taiga. This seems to be the main 'trinity'. His list was, however, not finished: he also addressed the God of the Tyuytyaha, the rivulet close to his camp, and a god in the form of a goose, a clan divinity. ${ }^{32}$

So usually prayers are a compulsory part of any reindeer slaughter and this, as well as feeding the spirits (see the next chapter) shows that each slaughter is a sacrifice. Most of those performed by Yuri correspond to this rule, but not all. When Eva and Liivo were at the summer camp in August 2009, the slaughtering took place on the last day of their stay. The family was moving south to Agan for a few days, to the funeral of one of Yuri's wife's elderly kin, and the camp was visited by a neighbouring Khanty couple. The slaughtering had been decided before, but the coming of these neighbours, whose relations with Yuri were not the best, ${ }^{33}$ led him to take advantage of the neighbour's better skills of lassoing and they marked the calves together. Then they chose a reindeer whose fur was already long enough to make it fit to be used, and they slaughtered it. Yuri's mood was not the best: the tension with the neighbours, the fact that it was too early to slaughter a reindeer, the forthcoming trip to Agan reflected on his disposition. Even the presence of the camera seemed to annoy him this time. Thus the slaughtering proceeded quite rapidly: all the men stood side by side, the men of the family closer to the reindeer, the neighbour standing behind, but still in the sacred space. And all the usual proceedings were respected, except the verbal ones. Yuri only commented about the cat that was expecting meat at some distance, and just killed the reindeer in the usual way without a single address to the gods. Moreover he, his wife and his sonin-law left the subsequent activities (skinning, cutting, washing and cleaning parts of the meat) to the neighbours. This reflects the absence of dogmatism, the flexibility that characterises his 'religious' practice.

\section{FLEXIBILITY IN YURI VELLA'S SPIRITUALITY}

What we call flexibility is the absence of any absolute rules in proceedings. There are ordinary features, but exceptions are always possible. We could also call this feature 'pragmatism'. It appears in different fields.

For example, as we have shown, sometimes the ceremonies are rigidly kept from recording, but sometimes filming is allowed. It depends on the nature of the sacrifice. The ceremony where Eva was asked not to use recording devices was carried out in order to prevent the death of his wife - therefore, the ritual was too serious and too urgent for Yuri to risk the efficiency of it by allowing it 
to be recorded. In other instances, for example, when Yuri slaughtered three reindeer for meat, the rituals had a more general nature and Yuri did not mind someone recording them, as long as the filmmaker or the researcher followed certain basic rules of behaviour during the ceremony, like staying behind the sacrificed animal and not crossing the line where other male participants of the ceremony were standing. And then there were ceremonies where Yuri was genuinely interested in having been filmed, as in the case of sacrificing the piece of white fabric we had brought with us.

As we have shown, there is no difference in nature between the slaughtering mainly for meat or slaughtering mainly for sacrifice - we use the word 'sacrifice' mainly in order to characterise the predominant scope of the slaughtering to be inserted into a continuous axis. The ritual may be simplified and the verbal dimension reduced, but the house gods must be fed with sacrificial blood. While for an explicit sacrifice all the camp will be physically present, when the ritual aspect is not emphasised, everyone's presence is not as compulsory. Once after the first snow in the autumn of 1999 one reindeer was slaughtered for meat as Eva was working in the log cabin. She was not called to attend, and she saw Yuri coming in with a bloody bunch of fur, opening the box situated on the sacred wall and 'feeding the spirits' with it. This showed that undoubtedly it was considered as a sacrifice. In other cases - as in the slaughtering of reindeer in August 2009 - we did not notice the feeding of the spirit dolls in the cabin. It may have been due to lack of attention from our side, but we cannot exclude that it just did not take place.

We have no clues about the reasons for the non-accomplishment of one rite or another; we have not conversed on this issue with Yuri himself. But we should take into account the possibility of very human reasons, such as fatigue (our hosts are ageing and may be tempted to reduce efforts to the minimum), stress, bad mood and other forms of mental disposition.

Another sign of dominant flexibility is the fusion of Khanty and Nenets traditions in Yuri's practice. Using fabric for sacrifices seems to be a Khanty custom $^{34}$ practiced also by the Forest Nenets in certain areas, mostly where sacred places are visited by both communities, but not everywhere ${ }^{35}$. We do not know to what extent using fabric in sacrifices is due to the regional Forest Nenets peculiarities and to what extent it is a syncretic feature of Yuri's offerings that he has borrowed from the Khanty. As we have demonstrated elsewhere (Niglas \& Toulouze 2004: 110), Yuri himself does not often draw a clear line between Forest Nenets and Khanty tradition and he tends to see the indigenous people of the region as one culture.

What we would like to emphasise at this point is that rules are not to be followed blindly, and that each person, each head of family knows when and 
how they may be adapted. Clearly, the interest and the welfare of the reindeer and the people are always taken into account. This is no peculiarity of Yuri's approach, but a general feature known in Siberian Arctic communities. Flexibility and mobility are general characteristics of the peoples' worldview and Yuri is no exception.

Still, this flexibility may have limits, and we suppose that the concrete definition of the limits is very much connected with the single individual's understanding. While being quite flexible in most matters, there are rules that must be complied with. We can formulate the hypothesis that there are general rules followed by everybody, no one even thinking of ignoring them, a kind of hard core on the axis, while others are submitted to individual choices and variations. There are rules that are particularly important for Yuri, according to our observation, and he is quite critical of their non-compliance by other performers. The fact that others may overlook them shows that they do not belong to the hardest core.

In his camp, when a sacrifice is performed, women do not take any active part before skinning. They are present at some distance (5-10 meters), staring, but not moving or bowing. They only join the men in the sacred area to take food from the sacrificial table. Yuri's wife does not participate in any spiritual practice (at least openly). However, there are different examples. For instance, once we watched on a VHS cassette a public ceremony performed in Khanty-Mansiisk on behalf of the indigenous Association to Save Yugra ${ }^{36}$ by the Northern Khanty writer Maria Vagatova-Voldina, who is a respected elderly woman. Yuri commented on this ceremony, highly disapproving of her "putting" herself forward in that position, while there were men available. She was most probably the oldest person present, and certainly no more of fertile age $^{37}$, but as there were younger men present, she broke some rules by performing or accepting to perform this sacrifice, moreover publicly. Clearly, this deed was not perceived as shocking by many Khanty, Mansi or Nenets, as it was organised by an institution whose members are natives. However, it is an institution in which women, and even younger women ${ }^{38}$, have played a central role from the very beginning, and it is probably their influence that has led to more flexibility in gender issues.

But for Yuri, an elderly man himself, a patriarch within his own family, flexibility has its limits, and the issue of gender roles is certainly one of them. He seems to be very keen on systematically separating the genders, as Eva had the opportunity to observe during all her fieldwork (Toulouze, forthcoming). We do not know enough about the Forest Nenets' traditional gender practices to appreciate whether this limit in flexibility is a documented or Yuri's own reinvented tradition. We may just observe that, according to Yuri's own words, 
compared with the Khanty, the Nenets tend to be much more relaxed about rules, and it is certainly the case with gender issues ${ }^{39}$. But practice reveals that it is certainly very important for him to emphasise male predominance in the spiritual sphere.

\section{AMBIGUITY IN YURI VELLA'S PERCEPTIONS}

Sometimes, we still have the impression that Yuri's position concerning spiritual matters is not as crystal clear as it would seem in the previous sections. We shall focus on two problematic points: his relation to shamanism and to filming. His views seem to be contradictory and ambiguous on both issues, at least to our understanding, and we shall try to unravel them.

\section{Yuri Vella and shamanism ${ }^{40}$}

Every adult man in the Khanty and Nenets environment is able to communicate with invisible agents in some ways. This is actually what any head of family does when he makes an offering. To transmit one's wishes to the gods does not require high esoteric skills, and the 'making of a god' shows very much the same, as above. But men who have more skills get in touch more easily with unseen beings, of whom some may even assist them. This mediation role is the function of shamans, who have both skills and techniques to get superior knowledge and abilities, who can be helped by spirits to find answers. The most famous among the Forest Nenets shamans was Kalliat ${ }^{41}$ from the Ngahany clan, Toivo Lehtisalo's main informant in 1914 (Lehtisalo 1959). In this region, shamans have generally disappeared. The persecutions against them in the 1930s have been well documented (Leete 2007). Yuri himself mentions them in his literary texts, especially in one story whose main character is the old man Kapitya-ai, a Khanty whose skills were so genuinely recognised by the Nenets that they gave him a Nenets name. Kapitya-ai was denounced to the Soviet authorities as a shaman and committed suicide thereafter (Vella 2008: 34-35). Actually, Yuri never says explicitly that Kapitya-ay, or his Nenets counterpart Yavunko (he too was so popular among the other ethnic group as to have been given a Khanty name), were shamans. He says they were wise old men who knew many stories. It is not difficult to understand, especially when reading a recently published story about Yavunko (Vella 2008: 27-29) that these old men had superior knowledge and skills. But Yuri is reluctant to use the word 'shaman'. 
One must of course be prudent in saying that there are no shamans any more, and one must not forget that there may be people practising shamanic skills while there is no wider knowledge of it. The Khanty are very secretive about their shamanic practice as well as their 'religious' practice in general, secrecy being a fundamental part of it (cf. Pesikova 2006). The Forest Nenets seem to be less so. ${ }^{42}$ The only thing we may say for sure about the Nenets, is that the last Nenets who had the reputation of being a shaman in the Agan basin was Yancha, whose son Pavel died in the 1990s as an old man. The memory of Yancha is caricatural: Yuri himself sings a song imitating Yancha, who was a very old man who would often drowse while beating the drum and singing about fly agaric. There is no full proof he was a shaman, but if we add it to his reputation, we may assume he might have been one. Actually Yuri had never seen the old man himself, only others imitating him. So, as often happens, a personal song is performed through several intermediate interpretations. The comical aspect of Yuri's performance is interesting: is it a way of showing shamans through ridicule? Is it a relic of Soviet practices, when shamanism was prohibited? Is it only a funny way for Yuri to perform a song? It is difficult to give a clear answer to these questions. We would suggest that political caution was not the only psychological reason at stake. Soviet materialist education has not left Yuri unscarred, and scepticism, while not totally acknowledged, may be expressed in that way. Anyhow, Yuri seems not to be willing to be explicit on this subject.

As far as the Khanty are concerned, the 'last' shaman in the Agan basin, Ivan Ivanovich Sopochin, whose character has been fixed in Lennart Meri's film about the bear feast, The Sons of Torum $(1990)^{43}$, is still alive in people's memory, as he died only in the mid-1990 s $^{44}$. Yuri knew him well, and is even better acquainted with Sopochin's son, Iosif Ivanovich, who is a very well known person in the Agan community. He is suspected of having inherited some of his father's abilities, but he is still not considered a full shaman and he tries to play the role of a leader in the community, though he seems to be much more intimidated by the oil industry than Yuri.

We mentioned the situation in the Agan basin because Yuri is actually deeply interested, even fascinated, by shamanism: it is clear when he watches recordings of Ivan Sopochin's drum playing in the film Refugees from Kogalym (Ernazarova 1991), as both Eva and Liivo have separately witnessed. Once in December 2000, when Liivo was filming some evening activities in Yuri's cabin, Yuri was again watching the film and commented that while one is playing the drum, one straightens up, becomes lighter. He is also in trouble with the definition of the word 'shaman'. In a sequence included in Yuri Vella's World (Niglas 2003), Yuri is watching a VHS recording of a German television programme, 
where he is presented as a shaman; in his smile, comments and tone one may read several concomitant attitudes: on the one hand it is clear that the suggestion of his being a shaman is seen and felt as absurd and ridiculous; on the other hand, he feels flattered by the idea. Actually this sums up the ambiguity of Yuri's attitude towards shamanism. What is shamanism, who is a shaman, who is or may be a shaman? And could he be a shaman?

The fact that this is an issue for Yuri becomes clear if you look into the glossary presented in the last issue of his Nenets journal Tilhivsama ${ }^{45}$. In this glossary, he tries to explain the notion of tadibja, which is the Forest Nenets word usually translated as 'shaman'. Yuri explicitly denies this connection: for him, to translate tadibja as shaman is a sign that the reader has understood nothing. This reveals that Yuri tries to disassociate the Nenets notion (seen as expressing something serious and important, highly symbolic of native communities' identity) from the Russian word for this phenomenon ${ }^{46}$, which is seen by Yuri as inappropriate. This shows his personal concern about the whole notion, and actually this may also be significant for the whole generation, for they themselves lack a living experience of shamanism as they have not been brought up with it. They have been accustomed to hearing this word used by Russians with a depreciative connotation, and even worse consequences. So the word is dangerous, and does not cover a stable notion, for during the repressions, among the people accused of being shamans, there were wise old men, mere bearers of tradition. Still, shamanic knowledge is part of the symbolic tradition of Siberian indigenous people, so it was necessary for Yuri to define his position towards it, as soon as he made the choice of accepting his cultural heritage. This may explain why he likes to emphasise his organic connection to shamanistic knowledge: he often, for example also in Yuri Vella's World, tells a story about his parents, who consulted a shaman one and a half years before he was born; the shaman predicted his birth (a boy), and that he would be the only child, as well as the early death of his father.

As a matter of fact, we have the impression that Yuri would very much like to be a shaman, but as far as we know, he is not one. He has hinted to us that he has no special abilities, and he may assert that as a fact, because he has probably checked himself, hoping to discover that actually he is one. But the facts were very clear and he definitely regretted not to be able to be in direct contact with the spirits. Nevertheless, as he writes in one of his short prose texts (Vella 2008: 34), anybody - not only a shaman - can beat the drum ${ }^{47}$. Yuri himself has one and, as he has told Liivo, sometimes, on special occasions, he beats it.

Still, he likes to entertain ambiguity; although, in a rational conversation he says that unfortunately he is not a shaman. However, he likes to recall the two stories an old man used to tell, one if he wished the next day would be 
very cold, the other to call for warm temperatures - as in the written version of this story (Vella 2008: 28-29). Yuri always finishes his storytelling by saying that he has used them himself to get the weather he wishes. As one of the main signs of one being a shaman is the ability to master the natural elements and especially the weather, he achieves thus - if by words only - his dream of having special gifts.

Apart from the abovementioned episodes in which Yuri was reacting to film images on a TV screen and telling a story about his birth, Yuri never talked about shamanism in front of the camera. We assume that it can be explained by his deep belief in shamanism. The forces that are engaged in shamanistic beliefs and rituals are too powerful to play with, although it would certainly help to attract media attention that is so vital for Yuri in order to achieve his political coals. But Yuri cannot pretend to be a shaman when he is not one - it could be dangerous for his life and for his family's welfare.

\section{Filming: public versus private}

Actually, as a public person, Yuri often relies on his native way of interpreting the world in order to achieve his goals. It is interesting to follow how he has used the President's reindeer story for media communication (cf. Niglas \& Toulouze 2004; Niglas 2005; Novikova 2000: online; Khanzerova 2009: online; Butenschön 2003: online). Another example is how, in April 1999, when, as mentioned above, he erected a conic tent in front of the local administration building in Khanty-Mansiisk and in order to give more weight to his message, he took advantage of a Nenets custom connected with death. He put inside the tent a doll that represented the administration, which was ill with 'oil plague'. He then referred to the Nenets practice of leaving a dead person in the tent, and transformed the tent into a tomb only by changing the direction of the opening door and turning it towards the West (Niglas 2005: 127). However, traditions and worldview are different from spiritual issues. Eva has heard Yuri discussing the Ob-Ugrian practice of the bear feasts. He denied in a conversation that these events belong to the 'religious' sphere: he considers them as a way of being. Here, we recognise the holistic feature of native spirituality. It would be wiser and more appropriate to use the concept of 'continuum' proceeding from the direct address to the gods toward the everyday practice of native culture, in which examples like the ones quoted above or the President's reindeer are situated in between.

He counts on the attraction of exoticism and uses it for achieving his own aims, which are meant to protect the land for future generations. He uses this 
tactic on several levels. Once, in the winter of 1999, while Eva was a guest in his camp, two cars full of Russians visited him. He was not deeply acquainted with the visitors. They brought him a bottle of vodka as a gift. Yuri, very much as we can imagine an indigenous chief, gathered them in his cabin; he delivered a very impressive speech both about the rules to be followed in the forest and about the deadly significance of vodka as a gift. His attitude, sitting and speaking like a patriarch, added weight to his message. We thus see that he is able to manipulate curiosity about exoticism.

Yuri has very much taken advantage of the media as a way to give publicity to his endeavours for he has understood the importance of it in forging public opinion and thus giving strength to social forces. Here we may mention two early experiences. In 1990, there was a wave of reindeer killings and reindeer helicopter hunting by oil workers. Yuri organised a demonstration closing the road to the oil field, and invited not only regional, but also international media (Swedish TV was on the spot). The erection of a conic tent in the middle of the square facing the regional administration in Khanty-Mansiisk in the spring of 1999 was also a highly mediatised event. We may wonder, seeing that he has used traditional customs - i.e., that the Nenets give reindeer to friends and relatives who are far away in order to follow their wellbeing - to send political messages to the Russian president if he has also used traditional religious practices to gain media attention, as has been done in the same region, for example by the Saving Yugra association, who organised public sacrifice ${ }^{48}$ and bear feasts. What are the uses of the sacred in the public sphere?

One of the public actions connected with the sacred realm is the denunciation of shameful acts committed by officials against what should be sacred. Some public appearances of these issues may be identified both in literature and in action. Some literary texts are devoted to the expression of Yuri's reactions to desecration.

More privately, Yuri reacts extremely painfully when oil companies intrude in sacred places. In the basin of the Vatyogan, a tributary of the Agan River, there is the abovementioned sacred place on the top of a hill (see above, the offering in 2009). The Nenets (and certainly also the Khanty) used to visit this place and make sacrifices and offerings. Yuri told us on camera that when he was working as a hunter in the vicinity in the 1980 s, there were reindeer antlers and skins all over the trees. When we were there, we could see only a few very recent ones hanging on the trees. The old ones had disappeared, and Yuri accused the oil workers of having removed them..$^{49}$ According to Yuri, the same oil company workers used to drive over the hill, until he informed them that for the natives it is a sacred place. Then Lukoil's workers came with a bulldozer and made a ditch to block the access for motorcars to the sacred place. But "they 
did not understand that the whole hill is sacred". And, for mysterious reasons, they planted an enormous metal pole on the top of the hill, probably as a geodesic landmark. Yuri explained to us in an angry voice that he was shocked, as he was also shocked when the newcomers did not respect cemeteries: for him, as he told us (the Western people), "it is like someone knocked a metal pole in the middle of a church". Moreover, although this does not reflect directly what sacred places represent for him, it shows the requirements for general respect for the sacred that he would expect to see followed.

There are several other examples of how newcomers have desecrated places important for the indigenous peoples. Close to the city of Raduzhnyi, a suburb of dachas has been built on the sacred place of the Kazymkin's clan. The little town of Novoagansk, $8 \mathrm{~km}$ from Varyogan, has been built on a cemetery. In Yuri Vella's World (Niglas 2003), he recalls the time when it was part of nature. The sad expression on his face is more eloquent than any words. The desecration of cemeteries is a bad newcomer habit from which the locals have suffered. Close to Lukoil's 7th department automobile base, at a distance of 150-200 metres from the lake, was the grave of Yuri's grandmother's mother-in-law, Evy. And as we have already mentioned, the leaders of the oil workers' settlement of Povkh, according to Yuri's story, all died some time after destroying the sacred place. However, this story remains a private conversation and we have the impression that it is too serious a question to make fun of and to manipulate for the mass media. Still, it was told to the camera. We have the impression that filming is something between totally public expression and an intimate conversation. Yuri knows that eventually part or all of it may become public, but everything depends on the filmmaker's editing. Could it be that for Yuri ethnographic filmmaking, based on a long-term relationship between the filmmaker and the film subject, is more accurate and delicate means of representing his inner reality than TV reportage or news programmes, which often focus on the superficial and sensational? Although Yuri has never clearly expressed his content with Yuri Vella's World, saying half-jokingly only that it is "an Estonian view" of his life, his eagerness to be filmed again in 2009 proved that he must have been rather pleased with Liivo's film.

We have seen in the case of a very serious sacrifice and in the case of shamanic activities that Yuri is reluctant to exploit the exotic 'religious' issue for other purposes; it acts in his life as a value per se, which is not to be desecrated for profane use. But these are extreme examples. We may still wonder where the border between the indigenous worldview and religious issues runs. Does Yuri himself draw a distinct border? Aren't clear borders a characteristic of Western scientific thinking, incompatible with the way Siberian indigenous peoples reflect on their own experience? 


\section{CONCLUSION}

The study of Yuri's connection to the sacred within his ontology shows one individual's possible approach. The comments above are an attempt to draw a possible model on the basis of what we were able to observe by living with him and his family, by filming him and following his discourse. Is it possible today to study these issues otherwise than to examine each individual in depth? Thanks to Lehtisalo, we have some representation of what could have been the understanding of the sacred by the Forest Nenets back in 1914 (Lehtisalo 1924). Later on they emerged from isolation and were exposed to the very strong influence of Soviet ideology for many generations. This led to a painful duality in their consciousness, while their worldview was basically holistic. The duality in understandings - materialism against animism -, with a double belonging - village against wild - has coerced each individual to negotiate ways of positioning themselves, of inventing their own ways out of the deadlock, of dealing with their own personhood and spirituality. Yuri's experience is particularly interesting, for he is an intellectual deeply conscious of himself. It is impossible to argue that he follows the path of his forefathers. He wishes to do so, but he is compelled to adapt, to recreate his identity, his tradition, in order to find himself and to look for support in the forces that are external to him.

His practice is serious and committed. Unlike many other ethnic activists, he does not exploit this sphere of spirituality for his struggle for indigenous rights. Although he is known to have participated in massive collective sacrifices, he has never organised one, albeit his imagination has proven to be very fertile when he looks for media-friendly forms to achieve his political aims. He has undoubtedly used what can appear as peculiarities of the indigenous worldview to promote his welfare and to draw attention to the needs of the local indigenous population, but he has not mixed his personal spirituality with the public sphere of protest and political expression.

However, as has been demonstrated in this article, Yuri is rather enthusiastic about being filmed, even when it comes to recording rituals and sacrifices. Thus, his reluctance to use spiritual matters in his public appearances as the testimonies of his life experience and indigenous identity is not absolute. His attitude towards filming religious practices is flexible, as it is also flexible towards other aspects of his socio-cultural reality. It depends on the nature of the particular ritual and perhaps also on the specific relationship he has with the person(s) behind the camera. In some cases filming can even be a sort of catalyst for a ritual, or at least have some influence on the proceedings of the ritual.

All in all, Yuri is very ambiguous and cautious when it comes to stating his religious understandings. On the one hand, due to his intellectual background, 
he is more than capable of rationalising along the lines of Western materialism. But on the other hand, as a person who is strongly aware of himself as a native, Yuri understands that it is absolutely vital to negotiate one's position with the spirits, to communicate with them. Yuri has learnt to play his role as spiritual leader in his own family, although he seems to be more at ease in the ordinary communication with spirits than trying to fit himself into the role of a shaman. Yuri is well aware of peculiar power coming from some people - Ivan Sopochin was undoubtedly a strong shaman -, but he tends to be critical of the notion, and more importantly, he cannot but reconcile with the reality that he does not master the necessary abilities. While indigenous spirituality plays an important role in the conscious construction of Yuri's personhood, the specific aspect of this spirituality - shamanistic experience - is too far out of his reach to be included in that construction or in the filmic representation of it.

In any case, this article is an attempt to outline a possible blueprint of a particular person's spirituality. We have found that the quest for a form of spirituality peculiar to the Western Siberian natives, without being theorised by Yuri, is very much present in his everyday life, while the influence of Soviet ideology is present in Yuri's caution both towards his visitors and towards the spiritual matter itself. This spirituality seems to be a late reconstruction, and as such it is both flexible on some aspects and rigid on others, as in gender matters. We achieved these results mainly on the basis of observation and filming. The next stage would be to conduct issue-centred interviews with Yuri, in order to discover what his own awareness is on the subject. As we have many hours of valuable video material on the topic, it would probably be fruitful to use it in interviews to elicit information from Yuri's conscious as well as unconscious mind. This will allow us to check the validity of our present deductions and give us a clearer picture of the mechanisms behind Yuri's way of constructing, or reconstructing, his personhood as an intellectual, as a native, and as a spiritual person. Studying Yuri Vella in depth gives us a deeper insight into one particular way in which humans could adapt to invading Western globalised thinking.

\section{NOTES}

1 This article was supported by the European Union through the European Regional Development Fund (Centre of Excellence in Cultural Theory, CECT) and the Estonian Science Foundation (grant No. 8335).

${ }^{2}$ For discussion on observational and participatory cinema, see also Nichols 1991; Young 1975. 
${ }^{3}$ Several authors have emphasised "that 'belief" in the interiorised sense that Christians usually use the term may not be applicable to other religious traditions" (Hann 2007: 385; see also Ruel 1982: 22-23, 27).

${ }^{4}$ Forest Nenets as well as Khanty traditionally practice patrilocal residence.

5 There were actually two books both titled Vesti iz stoibishcha, (News from the Camp). The first book (1991a) was published by a Sverdlovsk publishing house in a traditional way, with an editor who made slight changes (not political). Yuri was not satisfied with the changes and some months later published a new shorter volume at his own expense (1991b).

${ }^{6}$ For a complete list of Yuri Vella's books, see http://www.jurivella.ru/index.php/-raamatud--books.

7 He worked at the fish centre, as a post worker, etc.

8 The last time Liivo had filmed Yuri was in May 2001. But since then, Yuri has been filmed by others many times, both for documentary and for television (see, for example, Gretchikov 2005).

9 About the meaning of this word in Russian (kul'tura), see Grant 1995: 15-16.

${ }^{10}$ As one Nenets inhabitant of Varyogan observed to Eva in 2000: "Vy znaete, my zhe pervobytnyi narod!" (You know, we are a primitive people). Moreover, the Russian word tsivilizatsiia (civilisation) is commonly used to characterise the Russian culture as opposed to the primitiveness of the natives.

${ }^{11}$ In Russian - rodovye ugod'ia. In 1992, the Duma of the Autonomous Khanty-Mansi district passed a new law giving the natives this possibility. See also Jordan 2004: $30-31$.

12 Eva remembers from her fieldwork in 1999 an observation made by a Russian driver (from Ukraine), who had been living in Siberia for thirty years. While driving in the suburbs of Raduzhnyi, a town built in about 1985, the driver said: "Look at this: there was nothing here, and now there is an airport. And here there is a dacha quarter." Actually, the place where the airport now is was the summer pasture of Egor Stepanovich Kasamkin; the dacha quarter was built on the same clan's cemetery. See also Eremei Aipin's short story Pervoprokhodets (Aipin 1995: 172-173).

${ }^{13}$ Actually Yuri Vella is not the only intellectual from the indigenous peoples of the North who uses this way of explaining one layer of his culture, as Eva witnessed in 2004, when Eastern Khanty intellectual Agrafena Pesikova-Sopochina explained to her the landscape around her camp in the same way.

14 This is what 'white people' are called in Western Siberia. Actually this name is used in the whole of Siberia (Anderson 2000, etc.).

15 This aspect is emphasised by Irinarh Shemanovski, one of the last missionaries who worked with the Western Siberian Nenets (the Tundra Nenets) at the beginning of the 20th century (Shemanovski 2005: 14-21). 
${ }^{16}$ Art Leete has written (1997: 46) that the Khanty, who share many cultural traits with the Forest Nenets, shout during a sacrifice in order to draw the attention of the gods.

${ }^{17}$ For more information about the importance of a car in Yuri's life see Niglas 2011.

${ }^{18}$ In Nenets, a kapi is a non-Nenets, but native. Usually, in this area, it is the word used for the Khanty, but it may also refer to other ethnic groups (Selkups, for example).

${ }^{19}$ In 2009 Yuri Vella and his family moved to a new winter camp: the pastures surrounding the former one could no longer provide enough food for his reindeer.

${ }^{20}$ Yuri never consumes alcohol himself and he is usually very angry with people who do. But for sacrifices he accepts it, although he never joins in the drinking himself, and nor does his wife.

${ }^{21}$ Kaur Mägi has also had the experience of Yuri forbidding any recording or photographing during a sacrifice (oral information, June 2010). Actually we do not know how Yuri would have reacted if someone was making a documentary about him at that time. Would he have allowed recording the ritual because the would-be film could serve as a concrete benefit for his cause? We are inclined to believe that Yuri Vella, despite of his eagerness to use film for his political ends, would have been very careful turning this critical situation into a media event.

22 This idea of replacement in death is clearly very much present in the understanding of how the interaction between humans and forces functions: it is possible to steer the final direction of the strike. A good example is one comment Yuri Vella made to us in 2009 about the oldest inhabitant of Varyogan. Being asked whether this man was still alive, he observed with a look of disgust on his face: "Oh, yes, and he is not close to death. He feeds on his children: all of them are now dead; he avoided his own death by eating them. This man is dangerous." (See also Vitebsky 2005: 124, for quite a similar example of replacement.)

${ }^{23}$ Few prayers have been recorded from the Forest Nenets. We have some samples in Lehtisalo's Nenets texts collection (1947: 547-549) in different situations. Two of them are prayers accompanying a reindeer sacrifice as in our material. Still, except for having in both cases an address to Num, the main heavenly god, we do not recognise any formulas corresponding to the texts presented below.

${ }^{24}$ The authors of this article.

${ }^{25}$ Yuri Vella refers to the same land on the Vatyogan, which belongs both to the god and to the people who live there.

${ }^{26}$ Clearly a formula: see Vella 2008: 76.

${ }^{27}$ The Siberian rivers have many meanders. Some of them have become still pools isolated by land from their former river.

${ }^{28}$ Forest Nenets is a language that uses augmentatives and diminutives widely. Here both words "lichen" and "mushrooms" are in their diminutive form, because they are connected to reindeer calves. In addition to the reindeer's main food - lichen - Yuri Vella mentions mushrooms because reindeer are very fond of them. As a rule, the 
Nenets, Forest as well as Tundra Nenets, do not eat mushrooms themselves in order to leave them to the reindeer (Susoi 1994: 19).

${ }^{29}$ Yuri's explanation: "There have been good days until now, let them continue."

${ }^{30}$ Yuri's explanation: the Master of the taiga is responsible for the vegetable world, which is also threatened.

31 "Mother of the heaven, old man of the heaven, look at the offerings put here by these children. Let the children who walk on the earth walk without trouble. Try to give them a good time and good weather." (Text translated by Kaur Mägi.)

${ }^{32}$ All this information is due to the translation from Forest Nenets by Kaur Mägi.

33 The neighbour's herd grazed not far from the place in which Yuri's herd stayed in the rut period, and Yuri was afraid that the herds might get mixed. Moreover, the neighbours have made compromises with the oil workers that Yuri Vella does not approve of. Still, they keep seemingly friendly neighbourly relations.

${ }^{34}$ Eva has witnessed it among the Eastern Khanty. See also the description of a collective sacrifice, where the Khanty use fabric the same way Yuri does (Balalajeva \& Wiget 2004: 81).

35 There are data about using fabrics as offerings by the Forest Nenets: Zen'ko-Nemchikova reports, when mentioning an analogy with Khanty rituals, the Forest Nenets tradition of bringing to sacred places in collective sacrificing ceremonies fabrics in different colours, white being the colour for the spirits of the high world, of the skies. Unfortunately, she does not describe the ritual slaughtering of reindeer (Zen'ko-Nemchikova 2006: 238). Khomich does not exactly describe sacrifices, but gives a general overview, in which fabrics are not mentioned (Khomich 1995: 210, 219).

${ }^{36}$ In Russian: Associacia Spaseniye Yugry.

${ }^{37}$ Gender in indigenous cultures is a wider issue, not to be developed in this context. However, fertility is the basis of taboos to be followed by women: girls who are still not menstruating and women past menopause are seen as closer to men. Therefore sacral activities led by elderly women could be acceptable from this point of view. As Vella's wife is a Khanty, we have no information about Forest Nenets female cults.

38 The first president was Tatiana Gogoleva, a young Mansi woman, later a successful politician, who was assisted by Zoya Riabchikova, a young Khanty teacher.

${ }^{39}$ Even today the Khanty have customs that show how seriously gender rules are observed: the reluctance of elderly women to accept trousers in the younger's vestimentary practices, the women's reserved behaviour with male visitors according to Yuri Vella's own remarks, and the custom of hiding the face behind the scarf in the presence of male non-blood kin (izbeganie).

${ }^{40}$ It would certainly make sense to further develop the issue of shamanism today among the indigenous peoples of Western Siberia. While some researchers have touched upon it (Siikala \& Ulyashev 2010), the aim of this article is not to delve into the question in general, but to try to understand, based on Vella's practice, how he relates to it.

${ }^{41}$ On Kalliat, see Mägi \& Toulouze 2002. 
${ }^{42}$ An observation made to Eva in 1999 by Yuri Vella himself, who remarked that the Forets Nenets adapted much better to the new rules after the Revolution: they were the first around Varyogan to become members of the Communist Party.

${ }^{43}$ Lennart Meri was an Estonian writer and filmmaker, who made several films about Finno-Ugric peoples from the 1970s onwards. He later became the first president of Estonia after the country regained independence.

${ }^{44}$ About Ivan Sopochin, see Kerezsi 1995.

${ }^{45}$ At the beginning of the $1990 \mathrm{~s}$, Yuri Vella started to issue a paper in Forest Nenets - the first attempt to write this language, following his uncle Leonid Aivaseda's first number of the publication. It was a single sheet, either A4 or A3, with articles, poetry, riddles, photos and drawings, everything made by Yuri himself. He stopped publishing it after the eighth issue.

${ }^{46} \mathrm{We}$ are well aware that the international word 'shaman' is not a Russian word, but a loan from a Tungus language (Vitebsky 2005: 12). However, it is the word used by Russians and that is why we call it here functionally 'Russian'.

47 "The drum hangs on the wall. You would like to reach out and give it a beat, but you feel hesitant. Nowadays many raise a drum beat not in order to get power for their souls, but to fill their stomachs. It wouldn't be good if my children and my grandchildren would think that my art existed just to increase the family budget .... The drum hangs on the wall. And still, you would like to beat it so badly..." (Vella 2008: 34).

${ }^{48}$ See Leete 1997, 1999.

${ }^{49}$ Actually the oil workers are those who, according to Yuri, behave as no natives would. As a matter of fact, there are no other non-native people in the area besides the oil workers.

\section{FILMOGRAPHY}

Ernazarova, Raissa 1991. Beglecy iz kogalyma. [The Refugees from Kogalym.] Novosibirsk Telefilm.

Gerchikov, Vladimir 2005. Vella. 35 min. Studio Telemost.

Meri, Lennart 1990. Toorumi pojad. [The sons of Torum.] 59 min. Tallinnfilm (Eesti Telefilm, YLE TV 2, Institut für den Wissenschaftlichen Film).

Niglas, Liivo 2003. Juri Vella maailm. [Yuri Vella's world.] 58 min. mp doc, F-Seitse.

\section{REFERENCES}

Aipin, Eremey 1995. Na poroge v druguiu zhizn'. [On the threshold of another life.] Klyatvoprestupnik [Oath Breaker.] Moskva: Nash sovremennik.

Anderson, David G. 2000. Identity and Ecology in Arctic Siberia. The Number One Reindeer Brigade. Oxford University Press. 
Asad, Talal 1993. Genealogies of Religion: Discipline and Reasons of Power in Christianity and Islam. John Hopkins University Press.

Balalajeva, Olga \& Wiget, Andrew 2004. Handi kollektiivne põdraohverdus. Usk, olemasolu ja kultuuriline püsimajäämine tänapäeva Siberis. [Khanty collective sacrifice of reindeer. Belief, existence and cultural survival in today's Siberia.] Mäetagused 26, pp. 69-103.

Blue, James 2006. Rouch, Jean. Interview. In: Mark Cousins \& Kevin Macdonald (eds.) Imagining Reality: The Faber Book of Documentary. London: Faber and Faber, pp. 268-270.

Butenschön, Marianna 2003. Jelzin, Putin und die Präsidentenkuh: Vom einsamen Kampf des Rentierzüchters Jurij Wella gegen den Ölkonzern LUKoil. Freitag 03.10.2003, http://www.freitag.de/politik/0341-russland.

Golovnev, Andrei 1995. Govoriashchie kul'tury: traditsii samodiitsev i ugrov. [Speaking cultures: Samoyed and Ugrian traditions.] Ekaterinburg: UrO RAN.

Grant, Bruce 1995. In the Soviet House of Culture. A Century of Perestroikas. Princeton University Press.

Gray, Patty A. 2003. The Predicament of Chukotka's Indigenous Movement: Post-Soviet Activism in the Russian Far North. Cambridge University Press.

Hann, Chris 2007. The Anthropology of Christianity per se. Archives Européennes de Sociologie, Vol. 48, No. 3, pp. 383-410.

Jordan, Peter 2004. Ethnic Survival and the Siberian Khanty: On-going Transformations in Seasonal Mobility and Traditional Culture. Nomadic Peoples, Vol. 8, No. 1, pp. 17-42.

Kerezsi, Ágnes 1995. Osobennosti vostochno-khantyiskogo shamanizma v nashi dni. [Peculiarities of the Eastern Khanty shamanism nowadays.] Narody Sibiri. [Peoples of Siberia.] Moskva, pp. 38-53.

Kerttula, Anna M. 2000. Antlers on the sea. The Yup'ik and Chukchi of the Russian Far East. Cornell University Press.

Khanzerova, Irina 2009. Istoriia prezidentskikh olenei. [Story of the president's reindeer.] Narjana Vynder 01.08.09, http://www.jurivella.ru/index.php/2009-07-3013-15-45/81-2003.

Khomich, Lyudmila 1995. Nentsy. Ocherki traditsionnoi kul'tury. [The Nenets. Essays on Traditional Culture.] Sankt-Peterburg: Russkii Dvor.

Leete, Art 1997. Sacrificial Ceremony at Lake Num-To. Arctic Studies 1. Pro Ethnologia 5. Tartu: Eesti Rahva Muuseum, pp. 35-55.

Leete, Art 1999. Ethnopolitical Comments about the Sacrificial Ceremony at Lake NumTo. Arctic Studies 2. Pro Ethnologia 7. Tartu: Eesti Rahva Muuseum, pp. 21-26.

Leete, Art 2007. Muutused ja meeleheide: põhjarahvad ja nõukogude võim 1920.-40. aastatel. [Changes and Desperation: The Northern Peoples and the Soviet Power in the 1920s-1940s.] Tartu: Eesti Rahva Muuseum.

Leete, Art \& Vallikivi, Laur 2011a. Imitating Enemies or Friends: Comparative Notes on Christianity in the Indigenous Russian Arctic during the Early Soviet Period. Asian Ethnology 70(1), pp. 81-104, doi: 10.2307/41231392.

Leete, Art \& Vallikivi, Laur 2011b. Adapting Christianity on the Siberian Edge during the Early Soviet Period. Folklore: Electronic Journal of Folklore, Vol. 49, pp. 131-146. 
Lehtisalo, Toivo 1924. Entwurf einer Mythologie der Jurak-Samojeden. Helsinki: Suomalais-Ugrilaisen Seuran toimituksia.

Lehtisalo, Toivo 1947. Juraksamojedische Volksdichtung. Gesammelt und herausgegeben von T. Lehtisalo. Helsinki: Soumalais-Ugrilainen Seura.

Lehtisalo, Toivo 1959. Tundralta ja taigasta. [From Tundra and Taiga.] Helsinki: WSOY. MacDougall, David 1998. Transcultural Cinema. Princeton: Princeton University Press. Mägi, Kaur \& Toulouze, Eva 2002. About Forest Nenets Shaman Songs. Mental Spaces and Ritual Traditions. An International Festschrift to commemorate the 60th birthday of Mihály Hoppál. Ethnographica et Folkloristica Carpathica 12-13, Debrecen \& Turku, pp. 413-431.

Nichols, Bill 1991. Representing Reality: Issues and Concepts in Documentary. Bloomington: Indiana University Press.

Niglas, Liivo \& Toulouze, Eva 2004. Yuri Vella's Worldview as a Tool for Survival: What Filming Reveals. Perceptions of Worldview, Pro Ethnologia 17. Tartu: Eesti Rahva Muuseum, pp. 95-114.

Niglas, Liivo 2005. An individual's attempt of resistance to the colonial policy: Yuri Vella's play with visual media. In: A. Leete \& Ü. Valk (eds.) The Northern peoples and states: changing relationships. Tartu: Tartu University Press, pp. 112-141.

Niglas, Liivo 2011. Yuri Vella on the Move: Driving a Uazik in Western Siberia. Folklore: Electronic Journal of Folklore, Vol. 49, pp. 31-70.

Novikova, Natalya 2000. You need to have rights to be free, or "An oath on a bear's claw". English translation from the official periodical of RAIPON Mir korennykh narodov zhivaia arktika [Indigenous Peoples' World Living Arctic.] No. 3, http://www. npolar.no/ansipra/english/MKN/MKN03-16.html, last accessed on 10 June 2010.

Pentikäinen, Juha 1971. Maria Takalon uskonto. Uskontoantropologinen tutkimus. [The religion of Maria Takalo. A research into anthropology of religion.] Helsinki: Suomen Kirjallisuuden Seura.

Pesikova Agrafena 2006. Vzgliad iznutri kul'tury. [A glance from within a culture.] Khanty-Mansiisk: Poligrafist.

Pink, Sarah 2007. Doing Visual Ethnography. London \& Thousand Oaks \& New Delhi \& Singapore: SAGE.

Pink, Sarah 2009. Doing Sensory Ethnography. London \& Thousand Oaks \& New Delhi \& Singapore: SAGE.

Ruel, Malcolm 1982. Christians as Believers. In: J. Davis (ed.) Religious Organization and Religious Experience. New York: Academic Press.

Shemanovski Irinarkh 2005. Izbrannye trudy. [Selected works.] Ed. by L. Lipatova. Moskva: Sovetskii sport.

Siikala, Anna-Leena \& Ulyashev, Oleg 2011. Hidden Rituals and Public Performances. Traditions and Belonging among the Post-Soviet Khanty, Komi and Udmurts. Helsinki: Finnish Literature Society.

Susoi, Elena 1994. Iz glubiny vekov. [From the depth of centuries.] Tyumen: Tjumen' Komitet Obrazovanija Administracii Jamalo-Neneckogo Avtonomnogo Okruga, Jamalo-Neneckij Okružnoj Inst. Usoveršenstvovanija Učitelej.

Toulouze, Eva 2003. Iouri Vella ou la construction de l'utopie. Sibérie: Paroles et Mémoires. Slovo No. 28-29, pp. 193-211. 
Toulouze, Eva 2004. Muuseum kui ellujäämise vahend: Juri Vella kogemus. [Museum as Means for Survival: Yuri Vella's Experience.] Eesti Rahva Muuseumi 45. konverents Muuseumid ja tegelikkus. Tartu, 14.-15.04.2004. Ettekannete kokkuvõtted. [Museums and Reality. Summaries of conference papers.] Tartu: Eesti Rahva Muuseum, pp. 70-72.

Toulouze, Eva 2012 (forthcoming). Femme sur le terrain: difficultés et défis dans la taïga de Sibérie occidentale. Mélanges en honneur d'Anne-Victoire Charrin. Slovo.

Vella, Yuri 1991a. Vesti iz stoibishcha. [News from the camp.] Sverdlovsk: Sredneural'skoe Knizhnoe Izdatel'stvo.

Vella, Yuri 1991b. Vesti iz stoibishcha - kniga vtoraia. [News from the camp - second book.] Raduzhnyi: Raduzhninskaia gorodskaia tipografiia.

Vella, Yuri 2008. Veterok s ozera (7x7). [Breeze from the Lake (7x7).] Khanty-Mansiisk: Poligrafist.

Vitebsky, Piers 2005. The Reindeer People. Living with Animals and Spirits in Siberia. Harper Perennial.

Young, Colin, 1975. Observational Cinema. In: Paul Hockings (ed.) Principles of Visual Anthropology. The Hague: Mouton, pp. 65-80.

Zen'ko-Nemchikova, M. A. 2006. Sibirskie lesnye nentsy. Istoriko-etnograficheskie ocherki. [The Siberian Forest Nenets. Historical and ethnographical essays.] Ekaterinburg: Basko.

More information about Yuri Vella: www.jurivella.ru. 